\title{
Regional Trade and Investment Value Chains in South Asia: Perspectives from Pakistani Enterprises
}

\author{
Syed Shujaat Ahmed ${ }^{1,2^{*}}$, Asif Javed ${ }^{1}$ and Rabia Manzoor ${ }^{1,3}$
}

1 Sustainable Development Policy Institute, Pakistan

2 PhD Scholar, School of Economics and Management, Beijing University of Technology, China

3 PhD Scholar, Department of Economics, Clark University, USA

Corresponding Author (syedshujaatshah@hotmail.com)

Received:O1 Nov, 2019

Revised: $10 \mathrm{Dec}, 2019$

Accepted: 2 Jan, 2020

Published: $28 \mathrm{Jan}, 2020$

How to cite this paper: Ahmed, S. S., Javed, A., Manzoor, R. (2019). Regional trade and investment value chains in South Asia: Perspectives from Pakistani enterprises. Quest Journal of Management and Social Sciences, 1(2),165-180.

Copyright (C) 2019 by authors and Quest Journal of Management and Social Sciences

This work is licensed under a Creative Commons Attribution-NonCommercial-NoDerivatives 4.0 International License.

https://creativecommons.org/licenses/ by-nc-nd/4.0/

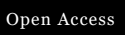

\begin{abstract}
Background: South Asian countries still maintained barriers to trade including regulatory restrictions on Foreign Direct Investment, non-tariff barriers and lack of banking channels. These restrictions are not only affecting the regional trade integration but also affecting the transfer of skills and technology among the member countries.
\end{abstract}

Objective:This study examines the factors that are inhibiting the development of regional integration for Pakistan in South Asia.

Methods:The study conducted interviews of business community in Karachi and Peshawar regarding regional trade, investment and value chains.

Results:The results pointed out that political difference with neighboring countries affect the regional integration in the form of lower trade and investment volume. Engaging in value chains is a way forward to promote trade flows and regional integration which will be beneficial for the trading partners in terms of economic growth and employment.

Conclusions:Pakistan contains weak investment outlay in South Asia as currently investment agreements with only Bangladesh and Sri Lanka existed. The reasons for lower FDI inflows in Pakistan include lack of political stability, inadequate infrastructure and non-transparent government regulations.

Implications:This study provides tentative picture of regional trade and investment in South Asia and the result generated can be used by concerned authorities, investors of those areas.

Recommendations:Simplifications in investment laws, piracy of intellectual property, relaxing current account restriction and single channel for streamlining information regarding support, opportunities, investment and market rules and regulations can enhance the investment volume.

Originality:This paper is original and is not published in other publications.

Keywords: Regional Integration, Value Chains, Trade Flows, Pakistan, South Asia.

Paper Type: Research paper

JEL Classification: E22, F21, O11, O53 


\section{Introduction}

South Asia is least integrated in terms of trade and connectivity as compared to rest of the world. The associations like European Union (EU), NAFTA, Brazil, Russia, India, China and South Africa (BRICS) are extensively successful when it comes to trade within the member countries. However, the platform of SAARC which is developed by South Asian countries is still not effective in developing trade relations within the region as only $7 \%$ of the exports are within South Asia (Ahmed \& Batool, 2017). The world is now moving towards deeper cooperation in the form of value chains which incorporates major share of trade, employment and GDP (Gereffi and Stark, 2011). The value chain activities can integrate several countries based on comparative advantage of a country in the certain production process. In the context, value chain can be the best strategy for South Asia to promote trade and investment relations.

In the seventh SAARC summit (1993), the member states agreed to promote regional investment (Mukherji and Behera, 2016). However, the development in this regard is still quite dismal as there is no significant cooperation in this field as well. The reasons for this weak cooperation involve regulatory restrictions on Foreign Direct Investment (FDI), tariff and non-tariff barriers, lack of banking channels etc. (Raihan, 2014). The prevalence of non-tariff barriers also restricts the transfer of skill and technology within the region (Ahmed et al. 2015). However, it is also a fact that there are supply side constraints in South Asia including poor logistics and business services which restrict the development of value chain among the countries (Ahmed and Javed, 2016). With improving transport and logistics services, regional supply chains can provide immense benefits especially for Small and Medium Enterprises (Serieux, 2012). This can reduce the trade costs and in turn demand for skilled workers can be increased through implementing technical (Harrigan and Reshef, 2011).

Escaith and Timmer (2012) defined that the transformation of global economy has made it possible to add value to goods and services in two or more countries before its final use. Sultana and Asrat (2014) focused on in-depth assessment of the potential of South Asian Free Trade Agreement (SAFTA) in South Asian Association for Regional Cooperation (SAARC) countries by highlighting mechanism to enhance socio-economic opportunities throughout the region. Similarly Chanda (2015) highlights the scope for and potential benefits from regional integration of services in South Asia. She found that there are regulatory, infrastructural, institutional and business environment related constraints in the region hindering the regional integration in services sector. In fact value chains are affected by the institutions and regulatory regimes in which they are being operated (Henderson et al, 2002). Value chains among South Asian countries will also resolve the employment crisis as Van Beisebroeck (2005) pointed out that engaging in value chains provide additional employment opportunities. Similarly highlighting the factors inhibiting development of regional integration framework (Khan et.al, 2007) mentioned that integration in the region failed to promote peace as regional tensions continue to inhibit the economic integration and interdependence. They also highlighted that economic globalization complicates regional integration as national agenda take priority thus eroding confidence building measures which can contribute to regional cooperation. Further examining the political economic factors as impediments to economic integration in the region, Kher (2012) highlighted trust deficit as 
one of the factors hindering the integration process alongside economic and strategic interest with political differences. Further with increased political will and commitment towards integration were highlighted as key factors for which larger countries have to play significant role. UN and Commonwealth Secretariat (2011) study explains that Bangladesh, India, Pakistan and Sri Lanka can develop supply chains in textile and clothing sector in order to attain cost competitiveness, and this will also increase exports across the region.. Better transport and logistics, allowing inclusion of SMEs and ease in cost of doing business and inflow of FDI are major factors to successfully promote regional value chains (Abe, 2013). Burnner (2013) is also off the view that South Asian countries competitive advantage relies upon investing and developing logistics infrastructure.

South Asia has immense potential for collaboration in terms of value chains which will be beneficial for each country to promote the trading activities. This is only possible through reducing the tariffs and duties on trade within the region. In this context, the present study focuses on the following objectives (i) to identify the potential areas for Pakistan to integrate with countries in South Asia. (ii) factors inhibiting the development of regional integration framework for Pakistan in South Asia.

The organization of the paper is as follows. Section 2 covers the methodology within which there is discussion for quantitative methodology followed by qualitative approach; Section 3 covers the situational analysis followed by results and discussion in Section 4; conclusions are drawn in Section 5; and policy recommendations are presented in Section 6.

\section{Research Method}

This section primarily takes into the account of methodology based on quantitative and qualitative approaches. Within quantitative approach business community was interviewed in Karachi and Peshawar where questions were asked related to regional investment, value chain and trade while keeping focus on doing business in the region by highlighting motivations, awareness and challenges.

Similarly within qualitative approach focus group discussions were conducted with the key focus on challenges being faced by business community while connecting within the region to trade. These focus group discussions were also conducted to highlight policy recommendations which can be incorporated into the economic and political agenda.

A survey of Pakistani firms from Karachi and Peshawar was carried to identify the potential areas of collaboration for local enterprises within the region. The enterprises pointed out key challenges which restrict the development of value chains.

\section{Quantitative Methodology}

In order to answer the questions related to potential areas of integration for Pakistan within South Asia and addressing challenges being faced, data was collected from Karachi and Peshawar. Objective of collecting this data from these two areas was because Karachi being business capital of Pakistan from where major economic activities of country are taking place along with availability of all type of ports to facilitate trade. Whereas Peshawar being connected to Afghanistan from where access to Central Asia can be made is the key reason of selection. 
From both cities total of 300 respondents were selected out of which 200 were from Karachi and 100 from Peshawar. Distribution of sample among cities was based on business population both based on type and size along with demography of the city.

Questions asked from the respondents were primarily related to: 1) years of trading and investment relations; 2) type of investment (Is investment related to goods production, services or trade) and 3) motivations and challenges to trade and invest.

\section{Qualitative Approach}

\section{Primary Data Collection using Key Informant Interviews (KIIs)}

To further address the research questions, in-depth interviews with established enterprises having businesses in Islamabad, Karachi, Lahore and Peshawar were conducted. For the interviews, a semi-structured questionnaire was developed to gather information on maximum aspects of regional integration and trade within South Asia. Information obtained was primarily related to challenges related to trade and connectivity in the region and how this connectivity can be further improved.

Beside KIIs, focus group discussions within the cities as mentioned above were also conducted. The objectives behind these focus group discussions were to find out Pakistan's current outlay while looking into value chains in trade and investment value chain. These two aspects were looked into by looking into the key questions related to regional trade and investment along with transit, supply chain and role of policy institutes. Within these focus group discussions questions related to enhancement of regional trade and investment by creating economic interdependencies and political strengthening along with role of transit trade in supply chain were discussed. Within the discussion where representatives from political parties were also involved stress was also there to address questions related to linking investment, trade along with value chain to economic agenda on the basis of which long term policies need to be formulated.

\section{Data Analysis and Result}

\section{Situation Analysis}

Pakistan's Trade and Investment linkages with South Asian Countries:This section provides a brief analysis of the trading and investment relationships between South Asian countries and Pakistan. We analyze the pattern of bilateral trade and investment with prospects for improving its future scope. The section contains the analysis of imports, exports and investment at the 6-digit level HS code along with inflow and outflow investment. Data has been obtained from the International Trade Center (ITC) and United Nations Commodity Trade (UNCTAD) database.

Pakistan's Export to South Asian Countries: Table 1 below illustrates Pakistan's export to South Asian countries from 2005-16. Pakistani exports have fluctuated widely during this period with more focus on Afghanistan with highest exports, whereas lowest exports going to Bhutan during this period. As can be seen from the information in Table 1, Pakistan's export 
to Afghanistan in this period was $\$ 19.12$ billion. Afghanistan was followed by Bangladesh where exports from Pakistan in this period were $\$ 6.61$ billion whereas Pakistan's export to India during the same period was recorded at $\$ 3.89$ billion. Sri Lanka is the fourth country where Pakistan is exporting within South Asia, during this period Pakistan's exports were $\$ 2.98$ billion. Countries such as Bhutan, Maldives and Nepal are countries where Pakistan's exports are minor in comparison to the major four economies.

Table-1: Pakistan's Export to Countries in South Asia (2005-16) in Billion Dollars

\begin{tabular}{|l|r|r|}
\hline Countries & Total Export & Percentage of World Export \\
\hline Afghanistan & 19.12 & $8 \%$ \\
\hline Bangladesh & 6.61 & $2.6 \%$ \\
\hline Bhutan & 0.000343 & $0.0001 \%$ \\
\hline India & 3.89 & $1.5 \%$ \\
\hline Maldives & 0.06 & $0.03 \%$ \\
\hline Nepal & 0.01 & $0.01 \%$ \\
\hline Sri Lanka & 2.98 & $1 \%$ \\
\hline
\end{tabular}

(Source: International Trade Center)

Similarly looking at the percentage comparison to exports going to world from Pakistan, it can be further argued that within the region it is very less. During the period of 2005-16, Pakistani exports to South Asian countries were only 13 percent of the total exports. Within this 13 percent exports, Afghanistan is having highest percentage i.e. 8 percent of the total world exports of Pakistan are going to Afghanistan. Afghanistan is followed by Bangladesh with 2.6 percent of the exports, India with 1.5 percent of the exports and Sri Lanka with 1.2 percent of the exports.

Pakistan's Import from South Asian Countries:Following data in Table 2 shows Pakistan's import coming from South Asian countries. As of during the period of 2015-16, Pakistan's import from India were the highest within South Asia. Pakistan's import were $\$ 17.76$ billion and it was 4 percent of the total imports.

In comparison to its exports to Afghanistan which was recorded for this period to be 8 percent, imports coming from Afghanistan were recorded to be minimal. Pakistan's imports were recorded to be $\$ 2.45$ billion during this period accounting for one percent of the world imports. Whereas with Bangladesh and Sri Lanka this trade linkage is found to be further weaker.

Table 2: Pakistan's Import from South Asian Countries (2015-16) in Billion Dollars

\begin{tabular}{|l|r|r|}
\hline Countries & Total Imports & Percentage of World Imports \\
\hline Afghanistan & 2.45 & $1 \%$ \\
\hline Bangladesh & 0.79 & $0.2 \%$ \\
\hline Bhutan & 0.004 & $0.001 \%$ \\
\hline India & 17.76 & $4 \%$ \\
\hline Maldives & 0.01 & $0.003 \%$ \\
\hline Nepal & 0.02 & $0.004 \%$ \\
\hline Sri Lanka & 0.79 & $0.2 \%$ \\
\hline
\end{tabular}


Figure 1: Pakistan's Export in South Asia against World

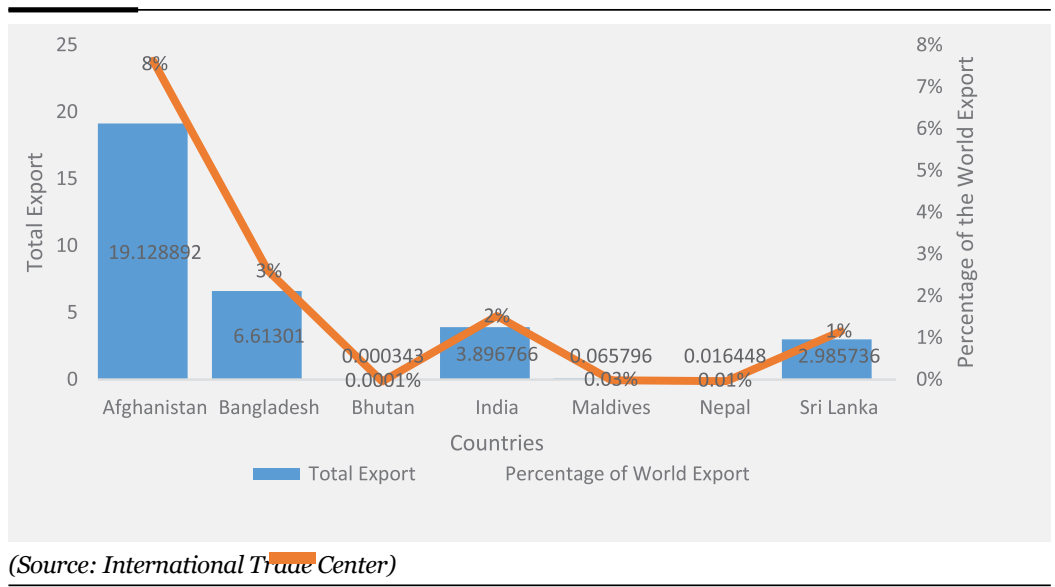

As can be observed from the data Pakistan was importing commodities of worth $\$ 0.79$ billion from Bangladesh and Sri Lanka during this period making it 0.2 percent of the total imports. On the contrary imports from Bhutan, Maldives and Nepal were recorded to be low due to lack of connectivity.

Imports from Nepal within these countries was the highest in terms of percentage i.e. Nepal's 0.004 percent, whereas from Maldives imports were recorded at 0.003 percent and from Bhutan imports were recorded at 0.001 percent of the total imports.

Investment outlay of Pakistan:When one looks at investment outlay of Pakistan, percentage of investment inflow to net investment during this period was recorded to be 97 percent whereas investment outflow to net investment was three percent. This percentage of net inflow was recorded to be third highest in terms of percentage within South Asia following Afghanistan and Bangladesh. This high trend of inflow was observed to be due to privatization, high sovereign debt issued internationally and increase in concessional long-term loans from the World Bank and Asian Development Bank (Khan, 2007). Beside these reasons post-October 2005 earth quake, majority of the investment came into the country for re-construction and rehabilitation process. There was fluctuation in post 2007-08 period mainly because of worsening financial crisis with weakened capacity of the international investors on account of falling corporate profits, heightened risks and reduced access to financial resources (SBP, 2009). ${ }^{1}$ There were also adverse impact of global financial crisis on FDI which was weakening the macroeconomic fundamentals and deteriorating law and order situation in the country. This, thus, resulted in declined investment.

During subsequent period, increase in FDI was attributed to privatization alongside green-field investment. Pakistan at the same time lacked adequate infrastructure, the dominance of green-field investment in the composition of FDI signifies the creation of long-term jobs and influx of technology and knowledge, which improved the country's human capital. New FDI which came during the period was concentrated in a few sectors such as telecommunications, finance and oil and gas exploration (Khan and Khan, 2011). 
Figure 2: Pakistan's Import from South Asia against the World

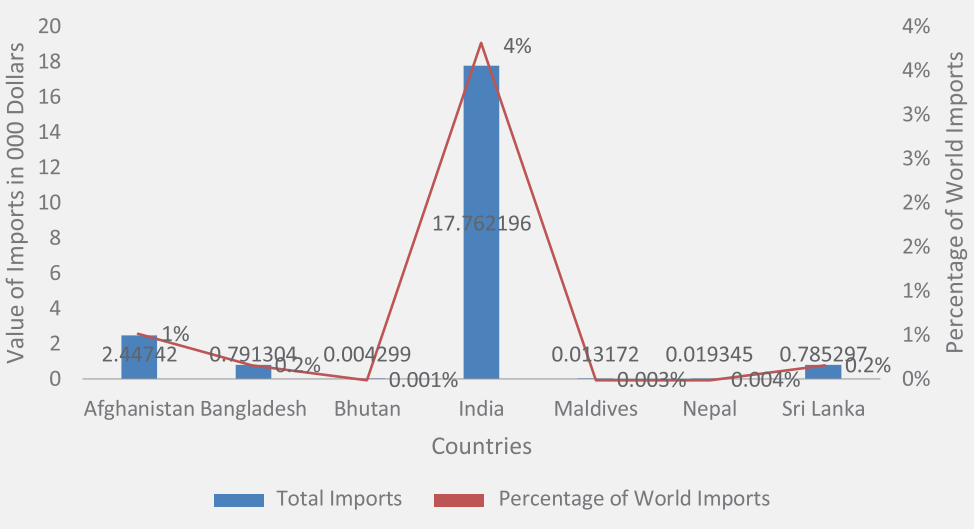

(Source: International Trade Center)

This increase in FDI seems insignificant when we compare it with other South Asian countries (Burki and Savitsky, 2000). The reasons for a lower level of FDI inflows in Pakistan include the lack of political stability, slow bureaucratic process, inadequate infrastructure facilities, macroeconomic imbalances, inconsistent economic policies of successive governments, delays in the privatization of state-owned enterprises, past disputes between foreign investors and the government, piracy of intellectual property, arbitrary and non-transparent applications of government regulations, and inconsistent political relations with major investing countries (Khan, 2007).

Table-3: Investment Inflow and Outflow for South Asian Countries

\begin{tabular}{|l|r|r|r|r|r|}
\hline \multicolumn{1}{|c|}{ Countries } & \multicolumn{1}{c|}{ Inflow } & \multicolumn{1}{c|}{ Outflow } & Net nvestment & Inflow/Net Investment & Outflow/ Net Investment \\
\hline Afghanistan & 1426.37 & -6.64898 & 1419.721 & $100 \%$ & $-0.5 \%$ \\
\hline Bangladesh & 15151.38 & 302.53 & 15453.91 & $98 \%$ & $2 \%$ \\
\hline India & 375170.4 & 134748.7 & 509919.1 & $74 \%$ & $26 \%$ \\
\hline Pakistan & 30378 & 946 & 31324 & $97 \%$ & $3 \%$ \\
\hline Sri Lanka & 8290.148 & 792.7911 & 9082.94 & $91 \%$ & $9 \%$ \\
\hline
\end{tabular}

Source: Unctad Stats

Within the investment framework of Pakistan, within South Asia Pakistan is having weak linkages. Pakistan has only one bilateral investment treaty within South Asia which is in force and that too with Sri Lanka. This investment treaty was signed in 1997 but there still exist weak investment support from Sri Lanka. During the time period FY 2012-17 net investment inflow was recorded at \$1.9 million. Parallel to Sri Lanka other investment treaty within South Asia which Pakistan have is with Bangladesh. This agreement was signed in 1995 and as per this agreement during fiscal period 2012-14 Pakistan received a net investment of \$4.2 million. This investment in accordance with the data was found to be discontinued after 2014.

Weak investment inflow outlay can be attributed to the reasons as FDI was discouraged by: 1) Significant public ownership, strict industrial licensing, and price controls by the government; 2) the inefficient financial sector with mostly public ownership, directed credits and

State Bank of Pakistan (2009), "Annual Report 2008-09: The State of the Pakistan's Economy”, Volume -I, State Bank of Pakistan:Karachi 
segmented markets; 3) a non-competitive and distorting trade regime with import licensing, bans and high tariffs(Khan and Kim 1999). Beside these reasons within the region political disconnect within the region is also one of the reason due to which Pakistan has weak investment linkages within the region. Pakistan's regional investment framework is also weak due to restriction on land ownership, capital requirements, local content requirement and lack of clear unified investment regime.

\section{Findings-I: Pakistan's Trade in South Asia}

Based on quantitative methodology, Pakistan's export within South Asia varies while looking at the type of products. Within South Asia export commodities which Pakistani enterprises are exporting primarily are related to agriculture and livestock, manufacturing and pharmaceutical products, food, textile and leather and services. Within different commodities which Pakistan is exporting within South Asia, primary focus of exports is on: 1) manufacturing and engineering products; and 2) food. Also in the region there is minor trade of Pakistan linked to agriculture and live stock and textile. In comparison to the goods export, Pakistan has the export of services with weak outlay within the region. It was observed that Pakistan was primarily included in law and banking services with key focus on banking services which it has developed across the region.

While looking at the export destinations based on the findings from the analytical exercise, it was found that Pakistan's majority of export is Afghanistan centric. About half i.e., 51 percent of the exports are going to Afghanistan followed by 16 percent exports going to India and Bangladesh. It is followed by 13 percent to Sri Lanka. Pakistan has very small percentage of exports going to Nepal and Bhutan. To Nepal out of total exports there are four percent of the exports going from Pakistan whereas one percent exports are going to Bhutan.

Further looking at the revenue percentage share of the exports those enterprises who have exports within South Asia only are having maximum revenue from the exports. A little more than half i.e., 53 percent of the enterprises who are having exports to the countries

Figure 3: Investment Integration in South Asia for Pakistan (2012-17)

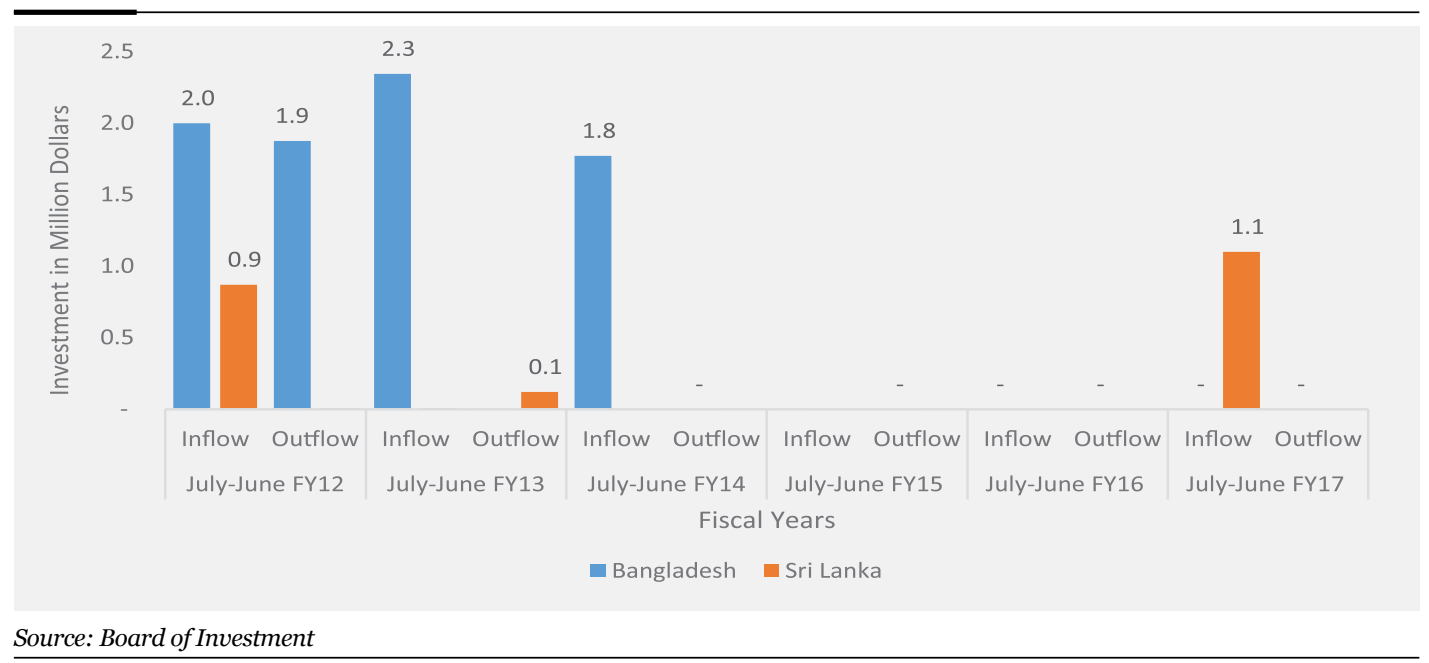


as discussed above have almost 90 percent of the revenue coming from the trade. It can be further noted that number of enterprises earning revenue between 50 to 75 percent is $16 \%$ and seven percent enterprises earn revenue between 26 to $49 \%$. About 16 percent of the enterprises are earning 11-25 percent. Enterprises earning about 10 percent of the total export revenue from South Asia ranges from 2 to 5 percent being the negligible ones.

Similarly looking at the import pattern, Pakistan is primarily importing manufacturing and engineering products followed by tea and medical equipment. Within manufacturing and engineering products, Pakistan is importing different metal sheets, appliances, mechanical tools and raw materials for such products. Beside these commodities being imported by Pakistan there are telecommunication imports in which primarily focus is on services and devices including telephone sets. Pakistan also import textile and related items from countries like Bangladesh and India. Pakistan also imports dry and fresh fruits from Afghanistan.

Within South Asian imports, Pakistan's major imports are coming from India. Pakiestan imports 41 percent of the total imports from South Asia from India. This is followed by 24 percent from Bangladesh whereas 18 percent of the imports are coming to Pakistan from Afghanistan and Sri Lanka.

\section{Challenges for Trade in South Asia}

Thus looking at the net-trade, it can be observed that Pakistan's trade connections within the region are weak. This weakness can be attributed to number of reasons along with the political misunderstanding prevailing other factors among South Asian countries. Pakistan's challenges related to trade are more linked to politics, trade diversifications and Tariff/ Non-Tariff Barriers. Within these major challenges there are particular notes for: 1) lack of functional economic corridors in the region; 2) conflict zones and mistrust between neighbors; 3) slow progress on trade facilitation and free trade agreements in the region; 4) and non-tariff barriers preventing skills and technology to transfer in the region as some of the most important issues requiring policy response. ${ }^{2}$

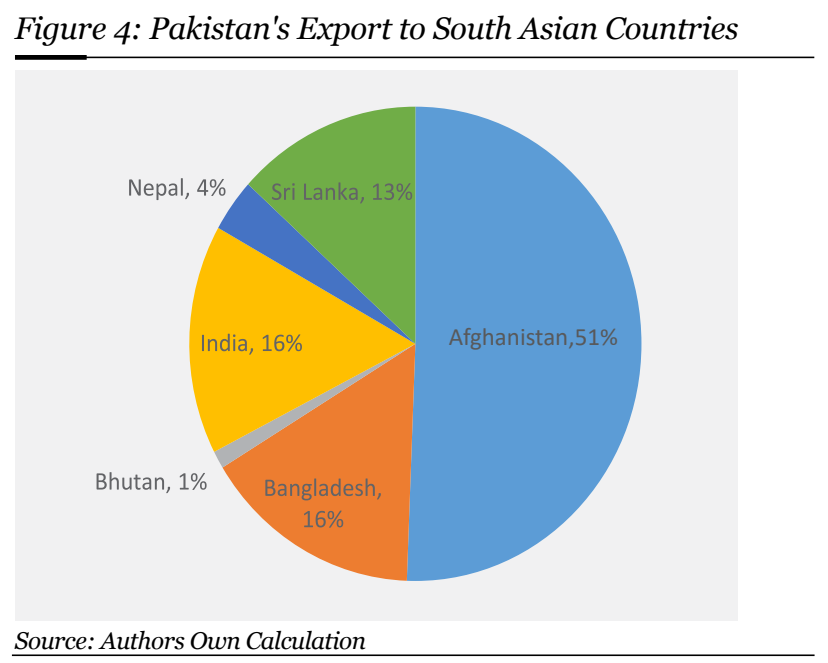

Similar Challenges were addressed by "Ahmed, V., Suleri, A.Q. and Javed, A., ${ }^{2} 015$. Strengthening South Asia Value Chain: Prospects and Challenges. South Asia Economic Journal, 16(2_suppl), pp.55S-74S”. 


\section{Politics and Trade}

Within the political challenges that Pakistan is facing, primarily focus is on conflict zones and mistrust factor with India. Due to the border conflicts and mistrust with India, Pakistan's trade with India is suffering. This suffering is despite of the creation of South Asian Association for Regional Cooperation (SAARC) in 1985 and the South Asian Free Trade Area (SAFTA) in 2004, economic integration within the region has been overlooked due to other economic activities within the region (Taneja et.al, 2015).

Figure 5: Pakistan's Export Revenue from South Asia

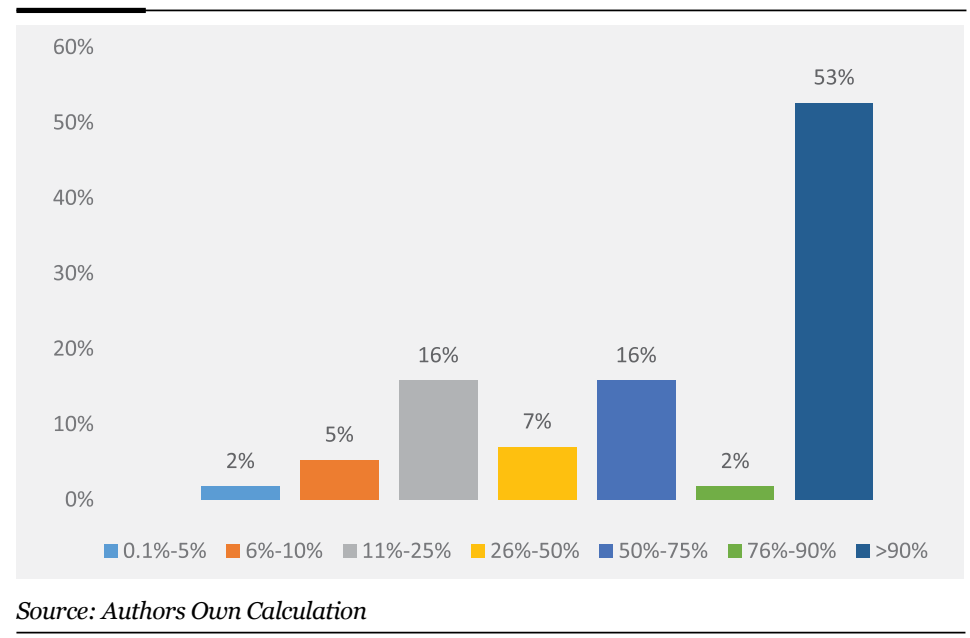

One of the main reasons behind this volatility in the region is the relationship shared by India and Pakistan. Thus, trade has been observed at very low level due to incidents of border skirmishes and disputes over the Kashmir issues, jeopardizing the utility of the entire bloc. These disputes have also influenced Pakistan's trade with countries such as Bhutan and Nepal. Therefore, in spite of positive developments such as the granting of MFN status to each other, both countries have continued to restrict their imports from the other. Progress in this regard has also been halted time and again by the resistance mounted by economic and political pressure groups in both countries (Rozenblat et al., 2017).

These disputes also challenge integration within the region and, in this regard, survey results found that politics and disputes associated with politics have affected consumer demands, orders and contracts. There are also disruptions in imported input supplies, business community face challenges related to visa issuance when they want to travel for their business trips. With the visa issuance challenge, there is also challenge of getting import items and export items cleared at the border.

This challenge regarding border clearance was pointed out by one of the respondents in the focus group discussion. He told that: "Pakistan is the only country where exporter has to confirm his export not only at Pakistan border, but also will verify it from Afghan Customs (Gumrick)". Due to current political differences and after ending of All Pakistan Transit Trade Agreement (APTTA) this verification of trade has been one of the core challenges that Pakistani business community is passing through. 
Figure 6: Pakistan's Import from South Asia.

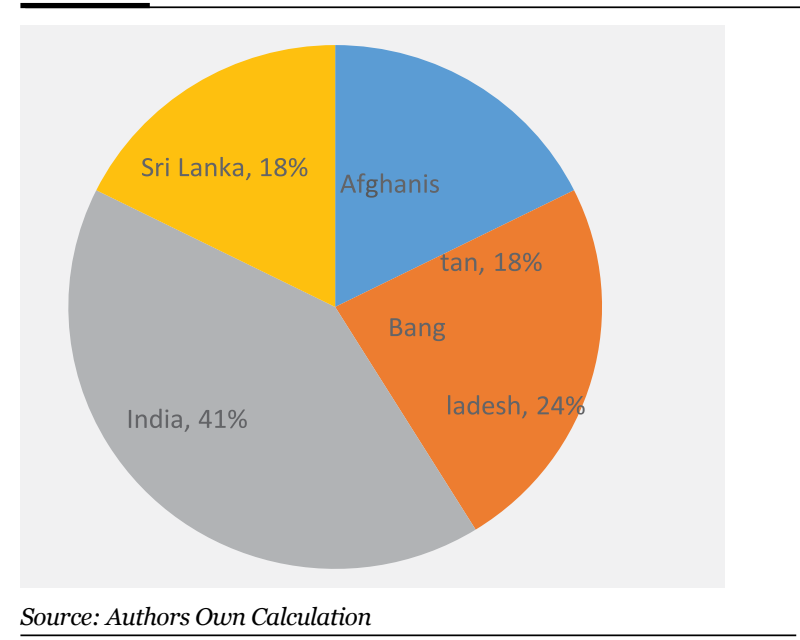

\section{Trade Diversification in South Asia}

Similarly looking at Pakistan's trade diversification within South Asia, it is evidently weak. This weak diversification is due to connectivity issues within the region. Connectivity issues primarily lead to the factor of functional economic corridors in the region. Weak connectivity is primarily due to major trade corridors which are outside South Asia. Pakistan's National Trade Corridor (NTC) clearly shows that major routes can be through only Afghanistan (East) and India (East). Other possible route map can be linked to China (North), Central Asian states for example Tajikistan, Kyrgyzstan, Uzbekistan, Kazakhstan and Turkmenistan along with Iran and Turkey (Ghulam and Vaqar, 2011). These connectivity issues were raised by business community in number of focus group discussions by also stating the fact that Pakistan has potential to trade within the region but for that role of government, chambers and trade facilitation institutions need to be aligned.

Similarly demand for Pakistani' product is also low within the region which was other key survey finding while identifying factors for low diversification in the region. Different studies have pointed out reasons related to type of products Pakistan is exporting. One of the key reasons being comparative advantage mainly in low value added consumer goods categories for example textiles and clothing, leather and its products and vegetables. Additionally comparative advantage is also in minerals and animals. When it comes to pharmaceutical products, chemicals, machinery and technology, Pakistan's advantage is relatively low in comparison to the South Asian partners.

This low comparative advantage also highlights the fact that enterprises in Pakistan lack capacity to produce quality goods. This weak capacity thus is one of the core challenges for Pakistan as its ability to meet demand is weak. Further Pakistan's weak trade diversification can be attributed to the weak custom procedures which are ineffective in comparison to the countries such as Bangladesh, India and Sri Lanka. These weak custom procedures are because of lack of national single window through which trade facilitation can be done with ease. Similarly high time of clearance both for export and import is also hindering Pakistan's trade connectivity within South Asia. 
Table-4: Effectiveness of Customs Procedure in South Asia

\begin{tabular}{|c|c|c|c|c|}
\hline Year & Bangladesh & India & Pakistan & Sri Lanka \\
\hline 2007 & 2.28421 & 3.61589 & $3 \cdot 38298$ & 3.98291 \\
\hline 2008 & 2.35261 & 3.6556 & 3.46425 & 3.67181 \\
\hline 2009 & 2.7654 & 3.91018 & 3.62376 & 3.66994 \\
\hline 2010 & 3.35977 & 4.03816 & 3.64718 & 4.21888 \\
\hline 2011 & 3.4 & 3.8 & 3.6 & 4.4 \\
\hline 2012 & 3.2 & 3.8 & $3 \cdot 7$ & $4 \cdot 3$ \\
\hline 2013 & $3 \cdot 4$ & 3.8 & 3.7 & 4.1 \\
\hline 2014 & 3.5 & 3.9 & 3.7 & 4 \\
\hline 2015 & 3.2005 & 4.26472 & $3 \cdot 355^{25}$ & 4.16609 \\
\hline 2016 & 3.2 & $4 \cdot 3$ & $3 \cdot 4$ & 4.2 \\
\hline 2017 & 3.6 & 4.6 & 3.7 & 3.9 \\
\hline
\end{tabular}

(1= highly ineffective to 7 = highly effective: Source World Development Indicator Data)

Beside time factor being high for Pakistan, weak trade facilitation in the form of storage and warehousing facilities along with high cost of clearance also contributes to weak trade diversification in the region.

\section{Finding-II: Pakistan's Investment in South Asia}

Based on quantitative methodology followed to collect data, this section highlights Pakistan's investment outlay in South Asia. Within this outlay discussion will be based on different type of investments along with motivation to invest in South Asia and challenges which enterprises from Pakistan are facing. It is important to note that most of the enterprises involved in investment within South Asia are related to trade and this trade is in accordance with the SAFTA agreement through which trade is being treated.

Investment within the region differs mostly in terms of its range and size of investment. Size of Outward Foreign Direct Investment (OFDI) differs. Within South Asia majority of the enterprises from Pakistan are investing less as found by survey. Maximum enterprises (over 20) are having 6-10 percent of investment in South Asia whereas there was only single enterprise investing about 75 percent in South Asia. Further survey results also revealed that only 20 percent of enterprises are having less than 5 percent of investment within South Asia.

\section{Pakistan-Afghanistan Investment}

While looking at the data collected from Pakistan's business centers and areas through which connectivity is majorly made i.e. Karachi and Peshawar in Afghanistan due to post-war situation investment inflow is taking place. Majority of the investment in this regard is going to trade support services. Out of total enterprises to which question being asked about investment in South Asia, 34 responded that there is investment with Afghanistan. Out of the enterprises investing in Afghanistan, 50 percent of the enterprises are involved in trade and trade related investment. There are 30 percent enterprises from Pakistan in accordance to the survey who are having goods production investment in Afghanistan. Similarly2o percent of the enterprises are involved in services investment. Type of businesses investing from Pakistan involved in Afghanistan include telecommunication, energy, food products, logistics, 
stationary items, paints and chemicals, cosmetic creams, beverages and cement. Out of these industries majority of the enterprises are from Karachi whereas Peshawar being border city has low number of enterprises investing in Afghanistan.

\section{Pakistan-Bangladesh Investment}

Investment going from Pakistan to Bangladesh is in accordance with the signed agreement back in 1995. In line of this agreement there was investment coming in the past and some of the enterprises from Pakistan are still doing investment in Bangladesh. In total of 300 respondents being surveyed total of 22 firms are found to be investing in Bangladesh. Out of the 22 firms, 59 percent of the firms are found to be indulged in trade supporting services investment, whereas 23 percent of the firms are involved in services related investment. Remaining 18 percent of the firms are involved in investment related to goods production. Firms that are involved in investment in Bangladesh from Pakistan include those dealing with textile, law firms, food products, agro-chemicals, stationary items, cosmetic creams, vehicles, biscuits and food products except biscuits.

\section{Pakistan-India Investment}

Besides having political differences, enterprises from Pakistan are investing in India. Total of 15 such enterprises are identified from the survey involved in the investment. In these 15 firms, 6 firms are involved in services related investment. Further 5 firms are involved in investment related to trade with India and 4 firms are involved in investment associated to goods production. Fifteen firms that are involved in investment include firms related to food products, agrochemicals, hoteling, textile, stationary items, marketing services and cement.

\section{Pakistan-Sri Lanka Investment}

Investment between Pakistan and Sri Lanka is in accordance with the bilateral investment treaty signed in 1997 between the two countries that came into effect in 2000. In accordance to this treaty within the sample, there are 14 enterprises investing in Sri Lanka. Out of these 14 enterprises, majority of the firms investing are associated to trade related investment followed by services provision related investment and goods production. From the responses it is found that there are 7 enterprises involved in investment related to trade, 5 related to service provision and 2 related to goods production. Firms that are involved in investing in Sri Lanka are involved in hoteling, electronics, mechanical, food products, logistics, pharmaceuticals, textile, cosmetic cream, cement and food.

\section{Challenges for Investment in South Asia}

While looking at the low investment volume from Pakistan. There are challenges being faced by business community while investing. Survey results revealed that majority of the challenges are linked to host procedural issues of FDI regulations, investment promotion agencies and host sentiment to FDI. Similarly Pakistani enterprises also have challenges related to cross border management and retention of labor. These cross border managements are also linked to clearance from different agencies at the border of entry. This challenge is primarily being faced by those having investment relations with Afghanistan and India. Survey results also revealed that firms investing in South Asia from Pakistan have connectivity and trade 
facilitation issues. Within trade facilitation majority of the challenges are related to custom support across the border and time for clearing the goods. It is also found that firms are facing restrictions while trading in goods. As is the case of pharmaceutical goods and chemical products which are either on negative or sensitive list in case of India. Out of 1209 products in the negative list as reported, 49 belong to pharmaceutical products. From survey results it is also found that factors that are inhibiting integration of Pakistan through its enterprises within South Asia include service trade restriction, access to finance, market outreach and other issues related to competition. As being discussed for challenges in case of trade, politics is another challenge which is inhibiting integration of Pakistan in terms of trade and investment within the region. Survey results also revealed this fact as one of the key challenge for investing within South Asia.

\section{Conclusion and Policy Recommendation}

Since as observed from the data Pakistan's integration within this region from trade and investment perspective is weak. This study identifies the factors inhibiting integration along with identification of those areas from where Pakistan can integrate with countries in this region. To address these objectives in this study we used both quantitative approach (Survey in Karachi and Peshawar) and qualitative approach (Key Informant interviews and focus group discussions). From the analysis it was found that Pakistan has potentials in manufacturing/engineering products and food for which it basically has higher demand in comparison to other goods. Besides these two commodities agriculture and livestock along with textile products are being exported to the countries within South Asia. Being one of the country and having shared border, Afghanistan is the only prime destination for Pakistan where it can export. Survey results also revealed this fact by highlighting the fact that 51 percent of the enterprises are involved in exports to Afghanistan followed by Bangladesh, India and Sri Lanka. The study contributed through analyzing the investment outlays of Pakistan within South Asia and revealed that Pakistan has weak investment outlay in South Asia with only agreements with Bangladesh and Sri Lanka. Out of 300 enterprises being surveyed about investment potential, it was found that enterprises are usually involved in investment linked to trade support services. Majority of the enterprises are found to invest in Afghanistan, Bangladesh, India and Sri Lanka. These are the most updated results from an enterprise survey which demands policy actions from the government. Key areas which can help in investment integration for Pakistan include sectors such as textile, cement manufacturing, food (including sea and non-sea food) and chemicals. It was found that factors like political differences with India is one of the key factors inhibiting Pakistan's integration within South Asia and trade remains low with India. Similarly current political differences with Afghanistan also hindered the trade integration. It was also found that due to lack of diversification within the region Pakistan also has weak integration in trade as far as countries of South Asia are concerned. This lack of trade diversification was primarily found to be due to lack of connectivity with absence of functional corridors in the region. This study also helped in finding out the factors such as product type which Pakistan is exporting has low demand in South Asia along with challenges of trade facilitation. Survey results also revealed that Pakistan's integration 
and potential to invest in South Asia is also weak because of trade restrictions, market outreach and challenges related to competition. Further for Pakistan challenge is in the form of non-tariff measures.

Based on the challenges, question is what needs to be done for improved trade and investment integration within the region which can also strengthen and bring closer SAARC countries. First there is need to relax capital controls by increasing limits on automatic approval and procedures in this regard should be streamlined. For this there is need to simplify the investment laws within the home country. Second, there should be relaxation in current account restrictions for making foreign exchange transactions for payment of services. There should be single channel to streamline information for support, opportunities, investment climate, rules and regulations market, for this there should also be streamlined procedure through which demand and supply mechanism can be channelized. Government agencies involved in trade supporting services should have market information through which support can be extended to find suppliers, distributors and clients. In this regard investment missions and commercial attaches should play their role through soft diplomacy and perception change within the region. Further those enterprises who are looking for technical assistance within the region should also be provided in accordance with SAFTA agreement and also there should be platform through which legal and management services can be availed while doing business with South Asian countries. Besides legal and management services, access to finances through different institutes should be provided with ease with for regulation framework to encourage business.

\section{Conflict of Interest}

The Authors declares that there is no conflict of interest.

\section{References}

Abe, M. (2013). Expansion of Global Value Chains InAsian Developing Countries: AutomotiveCase Study In The Mekong Subregion Bangkok: Economic and Social Combinations for Asia and Pacific (ESCAP.

Ahmed, V. \&Batool, S. (2017).India-Pakistan Trade: A Case Study Of The Pharmaceutical Sector' in N. Taneja, I. Dayal (eds), India-Pakistan Trade Normalisation: The Unfinished Economic Agenda, Springer, Singapore, pp. 219-244.

Ahmed, V., \& Ghulam, S. (2011). Trade facilitation for economic corridors in South Asia: the perspective of Pakistan. University Library of Munich, Germany.

Ahmed, V., \& Javed, A. (2016). Obstacles to South Asia Value Chains'. Trade Insight, 12(2).

Ahmed, V., Suleri, A.Q. and Javed, A., (2015). Strengthening South Asia Value Chain: Prospects and Challenges. South Asia Economic Journal, 16(2_suppl), 55S-74S.

Brunner, H. (2013). Can global value chains effectively serve regional economic development in Asia? (ADB Working Paper Series on Regional Economic Integration No. 110). Manila

Burki, S. J. and J. J. Savitsky .(2000). Globalization: An Agenda for Policy Analysis. Washington D.C: EMP Financial Advisors, LLC

Chanda, R., (2015) . Challenges to regional services integration in South Asia. South Asia Economic Journal, 16(2_suppl), 19S-38S. 
Desai, V. V. (2010). The Political Economy of Regional Cooperation in South Asia (No. 54). ADB Working Paper Series on Regional Economic Integration.

Escaith, H. and Timmer, M., (2012). Global Value Chains, Trade, Jobs, And Environment: The New WIOD Database. Retrieved from https://voxeu.org/article/new-world-input-output-database?quicktabs tabbed recent articles block $=0$

Gereffi, G., \& Fernandez-Stark, K. (2011). Global value chain analysis: a primer. Center on Globalization, Governance \& Competitiveness (CGGC), Duke University, North Carolina, USA.

Harrigan, J., and Reshef, A. (2011). Skill-biased heterogeneous firms, trade liberalization and the skill premium. Canadian Journal of Economics/Revue canadienned'économique 48 (3), 1024-1066

Henderson, J., Dicken, P., Hess, M., Coe, N., \& Yeung, H.W. (2002). Global production networks and the analysis of economic development. Review of International Political Economy, 9(3), 436-64.

Khan, A. \& Kim Y., (1999). Foreign Direct Investment in Pakistan: Policy Issues and Operational Implications. Retrieved from https://www.adb.org/publications/foreign-direct-investment-pakistan-policy-issues-and-operational-implications

Khan, M. A. (2007). Foreign direct investment and economic growth: The role of domestic financial sector (No. 2007: 18). Pakistan Institute of Development Economics.

Khan, M.A. and Khan, S.A., (2011). Foreign Direct Investment and Economic Growth in Pakistan: A Sectoral Analysis. Working Papers \& Research Reports, 2011.

Khan, S.R., Shaheen, F.H., Yusuf, M. \& Tanveer, A., (2007). Regional integration, trade and conflict in South Asia. Sustainable Development Policy Institute, Pakistan.

Kher, P., (2012). Political Economy of Regional Integration in South Asia. UNCTAD Background Paper No. RVC5, Geneva: UNCTAD.

Mukherji I N and Behera S K., (2016). Investment Cooperation for Deeper Economic Integration in South Asia. Trade Insight, 12 (6).

Raihan S., (2014). South Asia Economic Union: Challenges and Tasks Ahead. South Asia Economic Journal, 16 (2).

Rozenblat, C., Zaidi, F., \& Bellwald, A. (2017). The multipolar regionalization of cities in multinational firms' networks. Global Networks, 17(2), 171-194.

Serieux, J. (2012). Productive integration of LDCS into regional supply chains: The case of South Asia. UNCTAD Regional Value Chains Background Paper No. RVC, 2.

State Bank of Pakistan. (2009). Annual Report 2008-09: The State of the Pakistan's Economy. Volume -I, State Bank of Pakistan: Karachi. Retrieved from http://www.sbp.org.pk/departments/stats/ Funds Flow/FoF-2008-09.pdf

Sultana, S., \& Asrat, J. (2014). South Asian Countries in Regional Integration Perspective: A Critical Review. Journal of Business and Technology (Dhaka), 9(2), 43-59.

Taneja, N., Pohit, S., and Saini, R. (2015), India-Pakistan Trade Relations: An Introduction, In India-Pakistan Trade. Springer, Singapore.

United Nations, Commonwealth Secretariat. (2011). Potential Supply Chains in the Textiles and Clothing Sector in South Asia. United Nations, Commonwealth Secretariat. Retrieved fromhttps:// unctad.org/en/Docs/ditctncd2011d3 en.pdf

Van Biesebroeck, J. (2005), -Exporting Raises Productivity in Sub-Saharan African Manufacturing Firms, Journal of International Economics, 67(2), 373-391. 